Meta

Journal des traducteurs

Translators' Journal

\title{
On Translating Camfranglais and Other Camerounismes
}

\section{Peter Wuteh Vakunta}

Volume 53, numéro 4, décembre 2008

URI : https://id.erudit.org/iderudit/019665ar

DOI : https://doi.org/10.7202/019665ar

Aller au sommaire du numéro

\section{Éditeur(s)}

Les Presses de l'Université de Montréal

ISSN

0026-0452 (imprimé)

1492-1421 (numérique)

Découvrir la revue

Citer cette note

Vakunta, P. W. (2008). On Translating Camfranglais and Other Camerounismes. Meta, 53(4), 942-947. https://doi.org/10.7202/019665ar

\section{Résumé de l'article}

Les écrivains postcoloniaux recourent souvent à la créolisation et à l'indigénisation comme modes d'appropriation linguistique et culturelle. En d'autres termes, ces auteurs ont tendance à transposer les marques de leur culture sur leurs oeuvres. Cette étude examine la problématique de mixage de langues qui se pose souvent lors de la traduction des oeuvres littéraires. Loin d'incriminer les théories courantes sur la traduction, l'étude formule quelques suggestions sur la pragmatique de la traduction - la manière avec laquelle le traducteur littéraire cherche à saisir le sens des mots dans un texte plein de formes linguistiques indigenisées et hybridisées, plus particulièrement les formes créoles, pidgins, camfranglais et toute autre forme de langues hybrides. Il y a des avantages évidents dans l'indigénisation littéraire (i.e. une plus large audience, représentation de soi, etc.), mais comment ces bénéfices sont-ils perçus lorsque le langage littéraire est hautement contextualisé ? Dans quelle mesure la pidginisation est-elle en complicité ou en opposition avec les langues impériales ? Quelles sont les ramifications d'une telle complicité ou variance pour le traducteur? Quelles sont les formes d'agence discursives disponibles à travers la traduction?
Tous droits réservés @ Les Presses de l’Université de Montréal, 2008
Ce document est protégé par la loi sur le droit d'auteur. L’utilisation des services d’Érudit (y compris la reproduction) est assujettie à sa politique d'utilisation que vous pouvez consulter en ligne.

https://apropos.erudit.org/fr/usagers/politique-dutilisation/ 


\section{On Translating Camfranglais and Other Camerounismes}

\section{RÉSUMÉ}

Les écrivains postcoloniaux recourent souvent à la créolisation et à l'indigénisation comme modes d'appropriation linguistique et culturelle. En d'autres termes, ces auteurs ont tendance à transposer les marques de leur culture sur leurs œuvres. Cette étude examine la problématique de mixage de langues qui se pose souvent lors de la traduction des œuvres littéraires. Loin d'incriminer les théories courantes sur la traduction, l'étude formule quelques suggestions sur la pragmatique de la traduction - la manière avec laquelle le traducteur littéraire cherche à saisir le sens des mots dans un texte plein de formes linguistiques indigenisées et hybridisées, plus particulièrement les formes créoles, pidgins, camfranglais et toute autre forme de langues hybrides. Il y a des avantages évidents dans l'indigénisation littéraire (i.e. une plus large audience, représentation de soi, etc.), mais comment ces bénéfices sont-ils perçus lorsque le langage littéraire est hautement contextualisé ? Dans quelle mesure la pidginisation est-elle en complicité ou en opposition avec les langues impériales? Quelles sont les ramifications d'une telle complicité ou variance pour le traducteur? Quelles sont les formes d'agence discursives disponibles à travers la traduction?

\section{ABSTRACT}

Post-colonial creative writers constantly resort to creolization and indigenization as modes of linguistic and cultural appropriation. In other words, these writers tend to transpose the imprint of their cultural backgrounds onto their fictional works.This paper addresses the challenges posed by language mixing to the literary translator. Rather than interrogate the theories of translation, the paper seeks to bring new insights to the pragmatics of translation - ways in which the literary translator grapples with meaning discernment and rendition when faced with texts couched in indigenized and hybridized linguistic forms, namely creoles, pidgins, camfranglais, and other forms of hybrid languages. There are clear and obvious benefits in literary indigenization (i.e., a larger audience, self-representation, etc) but how do these benefits transform when these languages are contextualized in literature? In what ways is pidginization complicit or at variance with imperial languages? And what are the ramifications of such complicity or variance for the translator? What forms of discursive agencies are made available through translation?

\section{MOTS-CLÉS/KEYWORDS}

creolization, pidginization, hybridization, indigenization

Camfranglais is a hybrid language spoken in the Republic of Cameroon where English, French and close to 250 indigenous languages coexist. It con- sists of a mixture of French, English, Pidgin and borrowings from local languages. Kouega (2003:23) defines Camfranglais as "a composite language consciously developed by secondary school pupils who have in common a number of linguistic codes, namely French, English and a few widespread indigenous languages." Cameroonian youths tend to use this language as a communication code in order to exclude other members of the community. In other words, they use it to exchange ideas in such a way that the information would sound mysterious to non-members.

Some examples of Camfranglais expressions that one would hear in the streets and school circles in Cameroon include:

Tu play le damba tous les jours? = do you play soccer every day?

Je veux go = I want to go.

Il est come $=$ he has come.

Tout le monde hate me, wey I no know pourquoi $=$ everyone hates me but I don't know why.

J'ai buy l'aff-ci au bateau = I bought this stuff in the market.

Je vais te see tomorrow $=$ I will see you tomorrow

Elle est sortie nayo nayo = she went out very slowly.

Tu as sleep où hier? = where did you pass the night yesterday?

Tu as go au school? = did you go to school? Il fia même quoi $=$ what is he really afraid of ? ${ }^{1}$

It is the use of terms such as "damba" "see," "tomorrow," "pourquoi," "nayo nayo.", "fia," "bateau” "aff" and "buy" that may make understanding difficult for older people who are monolingual speakers of French or English. It is clear from these examples that the sentence structure of Camfranglais is calqued on the French syntactic structure. Each utterance above contains at least one English, Pidgin or indigenous language word like "play," "go," "come," "hate" "know," "nayo nayo," etc.

This language blend has been developed by urban youths to talk about daily events that are of interest to them, namely dating, entertainment, sports, money, physical looks and so forth. Camfranglais serves its adolescent speakers as an icon of "resistance identity" (Castells 1997). In other words, they create and constantly transform this sociolect by manipulating lexical items from various Cameroonian and European languages, in an effort to mark off their identity as a new social group - the modern Cameroonian urban youth - in opposition to other groups such as the older generation, the rural population and the elite. It is a composite language which resembles a pidgin in that it results from contact between several languages (Kouega 2003). To render their 
language incomprehensible to outsiders, speakers of Camfranglais use various techniques of word formation such as borrowing from various languages, coinage, elision, affixation, inversion, and reduplication.

Camfranglais first emerged in the mid-1970s after the reunification of Francophone Cameroun and Anglophone Southern Cameroons. It became fashionable in the late 1990 s, due partially to its use by popular musicians such as Lapiro de Mbanga, Petit Pays and others. Kouega (2003) gives a striking account of the social distribution of Camfranglais:

An impressionistic inspection of the profession of fluent Camfranglais speakers outside school premises reveals that they are peddlers, and laborers, hair stylists and barbers, prostitutes and vagabonds, rank and file soldiers and policemen, thieves and prisoners, gamblers and con men, musicians and comedians, to name just the most popular ones (Kouega 2003:513).

The lexical manipulation, phonological truncation, morphological hybridization, hyperbolic and dysphemistic extensions characteristic of Camfranglais reflect the provocative attitude of its speakers and their jocular disrespect of linguistic norms and purity, clearly revealing its function as an antilanguage (Halliday 1977). While this lingua franca functions like other slangs all over the world, it is somewhat unique in that it combines elements from French, English, and Pidgin and Cameroonian native languages.

In an article titled "Le Camfranglais, Un cousin du Verlan?” (1989), Michel Lobé Ewané draws striking parallels between Camfranglais and Verlan, a slang language spoken by young people in the French banlieue (suburbs). Verlan was invented as a secret code by youths, drug users and criminals to communicate freely in front of authority figures (parents and police). Here is a translation of Ewané's article:

Among the youths of every generation, there is always a speech code reserved for initiates. Camfranglais was invented by students at the University of Yaoundé about ten years ago as a result of the imposition of bilingual curricula on them by the State. It first saw the light of day at a time when students came face to face with the reality of a national bilingual education policy which compelled them to take courses in a language in which they were not proficient: French for Anglophone students and English for Francophone students. It started as a joke. Students wanted a mode of communication that would distinguish them from other segments of the population. Camfranglais has come to stay. It has become widespread and deep-rooted.
The scene described below is one of those incidents that occur on a daily basis in the streets of Yaoundé. It is an account of a traffic accident in which a posh car has just run over a dog. The forces of law and order are interrogating eye-witnesses. Among the people being interrogated, there is a recalcitrant young man who explains in an unusual lingo why he will not testify:

Tu nyai mon pied? C'est les mberés qui ont book. One day j'ai seulement nyé une aff, je n'étais pas inside, on m'a tcha, on m'a put au ngata. On m'a dit soté j'ai moto [...] Papa! a no dé fo'dé fo sé ka sé dans kin'a dog na dog for djintété. Dan kin'a matoa na matoa for djintété. Lep me je broute ma granut nayo yah!"”

This strange language is "Camgfranglais" and the story recounted is the subject of a popular play written by the talented Cameroonian playwright Essindi Mindja. Could this be described as linguistic vandalism or banditry? Is it rather an invention akin to the French argot called Verlan? Could this be perceived as the manifestation of cultural creativity conditioned by a linguistic environment in which official languages (English and French) have been taken hostage by indigenous languages?

In any event, Camfranglais, a hybrid language composed of borrowings from French, English, Pidgin and Cameroonian indigenous languages (Duala, Ewondo, Bassa, etc), has become a popular lingua franca amongst high school and college students in Cameroon. The rampant use of this language in academic circles is a great cause for concern for English and French language teachers and professors. According to a certain professor, this language translates not only the rejection by Cameroonian youths of foreign languages imposed on them but also the adoption of a sophisticated mode of expression that is intelligible to members of a select group. Camfranglais is a linguistic melting-pot comprising at least four different languages. Its vocabulary, syntax, imagery, accent and pronunciation are constantly being remodeled according to rules formulated on the basis of new findings by members of this restricted circle. The end result has been the birth of a jargon intelligible to high school and college students as well as the rank and file.

The syntactic structure of Camfranglais is calqued on French syntax. Inside the sentence, some words are replaced by either English words which may be conjugated like in French, or by words borrowed from one of the indigenous languages, namely Duala, Ewondo or Pidgin. Example: "J'ai tcha (pris) le métro et vous knowez (savez qui vient de 'to know') qu'il ne run (roule) pas vite."3 Another example: "Je te give (donne, ici, je te payes) huit kolo fap (8500 CFA Francs in Pidgin)." The 
origin and etymology of Camfranglais words are diverse.

It seems to me that Camfranglais has borrowed a lot from the French Verlan as exemplified in the following sentence: "La nga (ou la meute, c'est-à-dire la nana) dont je t'ai tok (parlé) m'a bondi (m'a snobé)." Recourse to the word "bondir" is justified by the impression the speaker wants to create in the mind of the listener. He wants to underscore the idea of being given the cold shoulder by a girl he admires. The image created by this usage may have far-reaching ramifications, especially when it is affiliated with an English language lexicon. For example, "Je suis filingué (attiré) par cette nga". 6 The word "filingue," coined from the English "feeling" could also be used in reference to a singer, performer or even a professor that one admires.

In sum, Camfranglais is chap (difficult) to understand, chap to tchatcher (speak). ${ }^{7}$ It is the lingo of students and the working class distinct from the business language of pacho (papa). Our pretty girls speak it too. There are countless synonyms at the disposal of Camfranglais speakers. The following words refer to "woman": Wa, Nga, Meute, Gnoxe, (the word ngoxer is often used to mean "make love," etc. Political and economic events in Cameroon have favored the rapid evolution of this language. Neologisms are being created day in day out to replace old ones. For example, on account of the economic crisis in Cameroon attributed to the severe austerity measures imposed on the citizens by the International Monetary Fund (MF), it is now common to hear Camfranglais speakers say: "Le Cameroun est fmisé (soumis aux contraintes du FMI)." The language has become so popular that renowned musicians are using it as a medium of self-expression. They find the humor, imagination and inventiveness of the anonymous creators of Camfranglais very appealing. Prepositions, concord and the gender of nouns are all muddled up. The context of communication is that of everyday life: friendship, school, love, courtship, parents, dating, leisure...

One of Cameroon's musical virtuosos, Lapiro de Mbanga, whose latest release caused a furor last summer, talked about "Big Katica for Ngola." The clip was censured for some time because the expression Big Katica actually refers to the President of the Republic. Katica is an indigenous word designating someone who invites friends to a game of poker, and Ngola is the original name for the capital city, Yaoundé. It is evident that Camfranglais has it own coded political lexicon. Camfranglais is considered 'cool' not only by high school and college students, but also by some youthful teachers. A few years ago, a high school teacher brought the question of Camfranglais into the limelight in a letter addressed to the editor of one of the local newspapers, Cameroon Tribune. Ironically, his letter was only published ten years later in a bi-weekly, Weekend Tribune in a column devoted to Camfranglais. Here is what the teacher said: "As far as I am concerned, Camfranglais is a language associated with ease of communication. We, the youths, want to simplify everything. In fact, we want to prove to everyone that we are learning several languages, and that we are capable of achieving alchemy of words... We must not lose sight of the fact that languages taught in school are poorly mastered."

This view was corroborated by remarks made by the national pedagogic adviser for the French language who claims: "I do not view the use of Camfranglais by our students as constituting a learning obstacle. However, if this new code became worrisome, it would be necessary to integrate it into our national language syllabi in order to make learners aware of the risks they may run by using it. The school milieu is governed by rules. So it is a safe-guard."

The birth of Camfranglais in Cameroon is not an isolated occurrence in Africa. Moussa or Nouchis (the lingo of the Loubards in Treichville) in Ivory Coast is analogous. Undoubtedly, these creolized linguistic varieties will soon become the language of theater and cinema, as has been the case with pidginized French used by humorous playwrights such Jean Miché Kankan and Daniel Ndo in Cameroon. With their black humor, these playwrights have no reason to be envious of French Verlan speakers.

All in all, it is clear from Michel Lobé Ewané's article that Camfranglais has clear social functions. It signals rebellion against authority and societal expectations. It is often associated with opposition to authority figures. In addition to switching to a code that most adults will not understand, Camfranglais provides a 'cover' for the use of taboo forms as well as 'covert' prestige for those who identity with this linguistic variety.

A number of Cameroonian fiction writers have begun to transcribe Camfranglais and other Camerounismes $^{9}$ in their creative writing. Here are a few examples of Cameroonianisms that a reader is likely to find in a Cameroonian novel or play of French expression:

On dit quoi? = quoi de neuf?

On va porter le même pantalon = je ne te lâche pas.

Le dehors est mauvais = les temps sont durs/ difficiles

Grever $=$ organizer/mener une grève.

Faites-moi le changement de 1000 francs $\mathrm{CFA}=$ donnez-moi la monnaie de 1000 francs CFA. 
Appuyer une nana $=$ avoir des rapports sexuels avec elle.

Cogner un plat de riz = le manger avec appétit. Fesser un enfant = lui donner une fessée.

On t'a cherché avec ton ami = ton ami t'a cherché.

On est ensemble! = A bientôt! /On se tient au courant!

Il se comporte $=$ il agit bien $/$ il prend ses responsabilités.

Tu es là depuis? = ça fait longtemps que tu m'attends? ${ }^{\text {?0 }}$

Lexical items borrowed from Cameroonian indigenous languages are gradually finding their way into Camfranglais. I have selected a couple of examples from Kouega's article for purposes of illustration:

Kongolibon $=$ close-shaven

Kumbu = big dish

Longo-longo $=$ tall and usually slim

Mbambe $=$ someone who does hard labor for a

wage

Mbut $=$ idiot

Mimbo $=$ alcoholic drink

Jobajo $=$ locally brewed beer

Odontol $=$ home-distilled liquor

Mola $=$ man

Mof-me-de! = piss-off!

Nayo-nayo $=$ very slowly

Ndoh $=$ money

Ndomo $=$ hit someone in a fight

Tara $=$ friend

Toum $=$ sell

Villakonkon = rustic; uncivilized person

Weh-heh! = exclamation expressing pity

Wolowoss $=$ prostitute

Jambo $=$ gambling

In his latest detective novels Cameroon's most popular novelist, Mongo Beti, has transcribed Camfranglais and other Cameroonianisms into French. In Trop de soleil tue l'amour (1999), Beti inserts Cameroonianisms such as: "Quand le grand chef disparaît de chez nous là pour passer deux mois à Baden-Baden là, tu vas même lui dire que quoi? Je te demande, Norbert, qui va même lui dire que quoi?" (120). Announcing the death and burial of his mother to his boss, the same character has recourse to a typical Cameroonianism: "Mais non, grand, ${ }^{11}$ ce n'est pas la même; nous sommes en Afrique non? Quand je dis ma mère, ce n'est pas toujours celle qui m'a accouché, ${ }^{12}$ vous savez bien; grand, vous êtes Africain, non?"(120). In Branlebas en noir et blanc (2000), Beti writes: "C'est comme les bordelles, ${ }^{13} \mathrm{il} \mathrm{faut} \mathrm{passer} \mathrm{à} \mathrm{la} \mathrm{casserole"}$ (23).

In a poem titled "Identity Crisis," Vakunta (2001) has recourse to Camfranglais to express his dual identity:
I don't quite know who I am.

Je ne sais pas au juste qui je suis.

Some call me Anglo;

D'autres m'appellent Frog.

I still don't know who I am

Je ne sais toujours pas qui je suis.

My name c'est Le Bamenda;

My name is L'Ennemi dans la maison;

My name c'est le Biafrais;

Mon nom is second-class citizen;

My name c'est le maladroit.

Taisez-vous! Shut up!

Don't bother me!

Ne m'embêtez pas!

Don't you know that je suis ici chez moi?

Vous ignorez que I belong here?

I shall fight to my dernier souffle

To forge a real name pour moi-même.

You shall call me Anglofrog!

Vous m'appelerez Franglo!

Shut up! Taisez-vous!

Don't bother me!

Ne m'embêtez pas!

Vous ignorez que I belong here?

Don't you know that je suis ici chez moi?

I shall fight to my last breath

To forge a real lingo for myself.

I'll speak Français;

Je parlerai English

Together we'll speak camfranglais;

C'est-à-dire qu'ensemble,

We'll speak le Camerounisme,

Because ici nous sommes tous chez nous (10).

A bon entendeur salut!

He who has ears should hear!

Anyone with the remotest interest in literary translation cannot help but ask the nagging question: what are the implications of this usage for the translator? As literary critic Paul Bandia has pointed out: "The difficulty of translating pidgins and creoles in the African novel lies in the fact that there is hardly any direct equivalent relationship between English-based pidgins and French-based pidgins in West Africa" (Bandia 1993: 103). Yet Camfranglais and other forms of Cameroonianisms are charged with socio-cultural information that reveals a lot about the characters in the narrative as we have seen in Ewané's article. It is, therefore, of crucial importance to retain these linguistic variants in the translation process because they are employed by the creative writer in order to capture the sociocultural context of the novels. Eugene Nida has underscored the importance of maintaining dialectal forms in the translation process as follows:

More frequently the dialect forms used by writers are either horizontal (geographical or vertical (socioeconomic) dialects, and rarely do authors or translators consistently represent all 
the details of such dialects, but at least certain easily recognized features are selected that serve to signal the type of dialect being used. A form such as "y'all" is supposed to typify Southern American English, and boid "bird" and "goil" are supposed to represent the Lower East Side of New York City. The problem for the translator is to find in a foreign language a dialect with approximately the same status and connotations. Rarely is the dialect match fully successful, for the values associated with a particular dialect are often highly specific (Nida 1976: 55).

The aim of this article has not been to provide a framework for resolving potential translation problems that may arise from the use of Camfranglais or other forms of Camerounismes in creative writing. Our objective has been to acquaint the reader with the emergence of a new linguistic code whose usage in African literature is likely to present the translator with peculiar problems. Africans of all backgrounds use blended languages such as Camfranglais, Pidgin, Moussa and Nouchis as a means of ensuring group solidarity within a community of practice. Creative writers use these mixed varieties to translate the socio-cultural contexts that inform and structure their narratives. Ivorian writer, Ahmadou Kourouma's recourse to linguistic hybridization in three of his novels, Les soleils des indépendances (1968), Monnè: outrages et défis (1993) and En attendant le vote des bêtes sauvages (1998) has been described by literary critic Gyasi as "a creative translation process that leads to the production of a Malinke text in French and the development of an authentic African discourse" (151). Kourouma echoes Gyasi when he evokes translation in his work: "J’ai donné libre cours à mon tempérament en distordant une langue classique trop rigide pour que ma pensée s'y meuve" $(8)^{14}$. The reader of Les soleils des indépendances is able to detect what may be termed a new African mode of storytelling. Kourouma uses a hybrid code which forces the non-Malinke speaker to refer to the novelist's native language and culture for signification. This is because the writer's use of 'Malinkalized' French leads to the production of a third code, characterized by an authentic African discourse.

An experienced translator working on the fiction of Mongo Beti and other Cameroonian writers would, I believe, achieve functional equivalence by having recourse to a communicative translation model. Using such a model is of critical importance given that a translation is supposed to have the same impact on the target language receptors as the original did on the source language recipients.

Peter Wuteh Vakunta University of Wisconsin Madison, Madison, U.S.A. vakunta@wisc.edu

\section{NOTES}

1. Francis Niba Ngwa. "New Language for divided Cameroon," <http://news.bbc.co.uk/2/hi/ africa/6376389.stm $>$, February $20^{\text {th }}, 2007$.

2. Tu m'as bien regardé? C'est vous les flics qui ont été à l'école. Un jour, j'étais témoin d'une affaire. Je n'y étais pour rien, mais on m'a arrêté et m'a mis en prison... On m'a dit que j'étais coupable. Papa! Ce genre d'histoire ne m'intéresse pas car ce chien c'est le chien d'un grand monsieur. Cette voiture c'est la voiture d'un riche. Laissez-moi en paix dans mon coin.

[Who are you taking me for? It's you, policemen, who have been to school. One day I was witness to an incident in which I was not involved. The police arrested me and threw me in jail. They said I was guilty. This kind of stuff doesn't interest me at all. This dog belongs to some big shot, and this car is owned by some rich person. Let me go in peace.]

3. J'ai pris le métro et vous savez qu'il ne roule pas vite. [I took the subway and you know that it doesn't run fast].

4. Je te payes huit mille cinq cent francs CFA [I will pay you eight thousand five hundred CFA francs].

5. La nana dont je t'ai parlé m’a ignoré [The girl I talked to you about has snubbed me].

6. Je suis attiré par cette nana (I admire this girl).

7. Difficult to understand and speak

8. Subjected to the constraints of the IMF.

9. Cameroonianisms.

10. "Camerounismes et le français parlé au Cameroun.," <http://www.Camerouninfo.net>, April $8^{\text {th }}, 2003$.

11. Patron.

12. Mis au monde.

13. Putes.

14. MoncefS. Badday (1970): «Ahmadou Kourouma, écrivain ivoirien", L'Afrique Littéraire et artistique 10, pp. 8-19.

\section{REFERENCES}

BAndiA, P. (1993): “Translation as Culture Transfer: Evidence from African Creative Writing," Traduction, Terminologie, Rédaction 6-2, pp. 55-78.

BandiA, P. (1993): “On Translating Pidgins and Creoles in African Literature," Traduction, Terminologie, Rédaction 6-2, pp. 94-114.

Beti, M. (1999): Trop de soleil tue l'amour, Paris, Julliard.

Beti, M. (1999): Branle-bas en noir et blanc, Paris, Julliard.

Castells, M. (1997): The Power of Identity, Malden, Blackwell.

EwAnÉ, L. M. (1989): «Le Camfranglais, Un cousin du Verlan?», Afrique Elite 36, pp. 18-19.

Gyasi, K. (1999): "Writing as Translation: African Literature and the Challenges of Translation," Research in African Literatures 30-2, pp. 75-87.

Halliday, M.A.K. (1977): Language as a Social Semiotic: The Special Interpretation of Language 
and Meaning, Baltimore, University Park Press.

Kouega, J.- P. (2003): "Word formative processes in Camfranglais," World Englishes 22-4, pp. 511539.

Kouega, J.- P. (2003): "Camfranglais: A novel slang in Cameroon schools," English Today 19-2, pp. 23-29.

Kourouma, A. (1970): Les soleils des indépendances, Paris, Éditions du Seuil.
Kourouma, A. (1990): Monnè: outrages et défis, Paris, Éditions du Seuil.

Kourouma, A. (1998): En attendant le vote des bêtes sauvages, Paris, Édition du Seuil.

NidA, E. (1976): "A Framework for the Analysis and Evaluation of Theories of Translation," in Brisling, R.W. (ed.), Translation: Applications and Research, New York, Gardner.

Vakunta, P.W. (2001): African Time and Pidgin Verses, Pretoria, Duplico. 